\title{
THE REVIEW OF RUSSIAN ECONOMIC LEGISLATION ${ }^{1}$
}

\author{
I.Tolmacheva, Yu.Grunina
}

In July 2013, amendments were introduced into Part Four of the Civil Code as regards state regulation of relations in the sphere of intellectual property; procedure was specified for intestate succession of escheat property into ownership of a municipal entity and constituent entity of the Russian Federation; the age of a foreign national at which he/she has the right to work in the territory of the Russian Federation has been established; it is established that when a foreign national stays in the Russian Federation under an ordinary work visa he/she can study at an educational establishment in the Russian Federation without securing a change in the purpose of the visit to the Russian Federation; from September 1, 2013 the procedure for acknowledging of the documents on education and qualification issued by Russian educational establishments, as well as those of RSFSR and the USSR will be renewed.

\section{Federal Laws of the Russian Federation}

1. Federal Law No.222-FZ of July 23, 2013 on AMENDMENT OF PART FOUR OF THE CIVIL CODE OF THE RUSSIAN FEDERATION

Amendments introduced in Article 1246 of the Civil Code of the Russian Federation concern state regulation in the sphere of intellectual property.

Issuing of regulatory and statutory acts for the purpose of regulation of such relations in the sphere of intellectual property as are related to entities of the copyright and related rights is carried out by authorized federal executive authority which effects normative and legal regulation in the sphere of copyright and related rights.

Issuing of regulatory and statutory acts for the purpose of regulation of such relations in the sphere of intellectual property as are related to inventions, useful models, industrial samples, computer software programs, data bases, layouts of integrated electronic chips, trademarks and service marks and names of places of origin of goods is carried by the authorized federal executive authority which effects normative and legal regulation in the sphere of intellectual property.

Legally important actions as regards state registration of inventions, useful models, industrial samples, computer software programs, data bases, layouts of integrated electronic chips, trademarks and service marks and names of places of origin of goods, including acceptance and due diligence of relevant applications for issuing of patents and licenses which certify the exclusive right of their holders to the specified outputs of intellectual activity and means of individualization, while in cases provided for by the law to other activities related to legal protection of outputs of intel-

1 The review was prepared with assistance of the KonsultantPlus legal system. lectual property are carried out by a federal executive authority which is in charge of intellectual property.

As regards selective achievements, the above function is carried out by authorized federal executive authority which effects regulatory and legal regulation in the sphere of agriculture and the federal executive authority on selective achievements.

It has been established that the Government of the Russian Federation has the right to set the minimum rates, procedure and deadlines for payment of royalties for service inventions, service useful models, service industrial samples, while for individual types of utilization of entities of copyright and related rights it is in a position to set the minimum rates and the procedure for collection, distribution and payment of remuneration.

2. Federal Law No.223-FZ of July 23, 2013 on AMENDMENT OF ARTICLE 1151 OF PART III OF THE CIVIL CODE OF THE RUSSIAN FEDERATION

Amendments were introduced into Article 1151 (2) of the Civil Code of the Russian Federation. The above amendments deal with the procedure for intestate succession of escheat property into ownership of a municipal entity and constituent entity of the Russian Federation.

If there are no legal heirs or heirs by devise, nor does any heir have the right to inherit, or all the heirs are barred from succession or no heir accepted succession or all the heirs refused to accept succession with none of them specifying that he/she has waived succession in favor of another heir, the estate of the deceased person is deemed an escheat property.

In accordance with the procedure for intestate succession, assigned in ownership of an urban or rural settlement and municipal district (as regards inter-settlement territories) is the following escheat property situated in the respective territory: 
- housing;

- a land plot, as well as buildings, constructions and other real property units situated in it;

- a share in the title to common property to specified real property units.

If the above units are situated in the constituent entities of the Russian Federation - cities of federal importance Moscow and St. Petersburg - they are assigned into ownership of that constituent entity of the Russian Federation.

Amendments become effective from the day of their official publication.

Federal Law No.204-FZ of July 23, 2013 on AMENDMENT OF FEDERAL LAW ON LEGAL STAUS OF FOREIGN NATIONALS IN THE RUSSIAN FEDERATION AND LABOR CODE OF THE RUSSIAN FEDERATION

Foreign national has the right to work in the Russian Federation if he/she reached the age of 18.

An exception from that rule is applied to motion picture entities, theatres, drama and concert entities, circuses and athletes under the age of 18.

Also, the Labor Code of the Russian Federation is supplemented with norm which introduces exemption from the general procedure conclusion of labor agreements as regards labor agreements which are entered into with foreign nationals..

Federal Law No. 203-FZ of July 23, 2013 ON AMENDMENT OF THE FEDERAL LAW ON THE LEGAL STATUS OF FOREIGN NATIONALS IN THE RUSSIAN FEDERATION AND INDIVIDUAL STATUTORY ACTS OF THE RUSSIAN FEDERATION FOR THE PURPOSE OF CREATION OF ADDITIONAL FAVORABLE CONDITIONS FOR EDUCATION IN THE RUSSIAN FEDERATION OF FOREIGN NATIONALS AND STATELESS PERSONS

In staying in the Russian Federation under an ordinary work visa a foreign national is allowed to take training at an educational establishment in the Russian Federation without changing the purpose of the visit to the Russian Federation.

It has been envisaged that the employer and customer of jobs (services) have the right to attract and use foreign workers without a permit to attract and use foreign workers in case foreign nationals are full time students in the main vocational program at vocational training institutions or educational establishments of higher learning with state accreditation.

The specifics of labor activities by individual categories of foreign nationals which are full time students in the Russian Federation have been established.

Also, it is specified that the federal law or international agreements of the Russian Federation may set the specifics of entry to the Russian Federation, stay in the territory of the Russian Federation and departure from the Russian Federation by foreign nationals or stateless persons who enter (were enrolled in) educational establishments of the Russian Federation in accordance with international agreements of the Russian Federation which provide for engaging of respective categories of foreign nationals and stateless persons in education in the Russian Federation.

\section{Resolutions of the Government of the Russian Federation}

Resolution No.611 of July 20 ON APPROVEMENT OF RULES OF ACKNOWLEDGEMENT OF DOCUMENTS ON EDUCATION AND (OR) QUALIFICATION

The result of acknowledgement of documents on education and qualification is apostil on those documents.

Acknowledgement of documents is carried out by authorized regional authorities which deal with applications submitted by persons in writing or e-mail via Web-site: gosuslugi.ru.

Both the structure of the application and the list of documents enclosed thereto are specified.

It is determined that the authorized regional authority receives applications and documents irrespective of the place of residence of the applicant and the location of the entity which issued the document on education or qualification.

The period within which the issue of acknowledgement of the documents is considered is 45 days from the day of receipt of application and documents enclosed thereto.

The resolution will become effective from September 1, 2013. 